\title{
Stimulative Increase of Fertility in Uzbekistan in Accordance with the World Experiences
}

\author{
Xudjageldiyev Chorshanbi Pardayevich ${ }^{\mathbf{1}}$ \\ ${ }^{1}$ Senior teacher, Termez State University, Uzbekistan \\ Email:xudjageldivev_ch@bk.ru
}

\begin{abstract}
The article deals with world's experience in stimulating development fertility of the soil used in agriculture. The author gives recommendation using it in Uzbekistan.

Keywords: stimulation, fertility soil, agricultural soils, reclamation state, effectiveness credit (finance) plugging soil.
\end{abstract}

\section{INTRODUCTION}

The success of the agrarian reforms in Uzbekistan, largely depends on the study and generalization of the achievements in the area of world experience and their introduction into business practices, taking into account the socio-economic development of the Republic. It must be emphasized that to stimulate fertility improvement of land used in agriculture, particularly irrigated land, has accumulated rich experience in the world. In this sense experience in practice developed countries is significant. However, it should also not be missed the attention that, unlike the Republic of Uzbekistan, in the most developed countries of the world the land is privately owned.

The USA. In the United States of America, the main form of agricultural production are farms where they are divided into small and large. To include a small farms with annual incomes less than 250 thousand dollars. Large profited farms of more than 250 thousand dollars. [3, p.321] The system of agricultural support from the government in the USA occupies a considerable place is occupied by the government programs on the production of agricultural products, in which special attention is paid to maintain and improve the fertility of cultivated land. Realization of the program of fertility, improving its ameliorative condition is mainly financed by the State. 26 percent of the work carried out in the framework of government programs on the production of agricultural products, carried out by small farms, others by large farms. Deserves attention that if large farm irrigation and reclamation work performed at their own expense, in small farms 95 percent of the expenditure required to carry out the above mentioned, allocated by the state. [3, p.322]

The main directions of ordering agriculture by the state consist of purchases and mortgage, guaranteed prices and direct payments for the reduction of arable land. In ordering the state of agriculture is of particular importance guaranteed prices for agricultural commodities. To date, guaranteed prices provided those farmers who have specific conditions set in front of them, in particular, for the protection of water and land resources, increasing the fertility of cultivated land. [1, p.35]

In the USA Department of Agriculture operates the State Land Service. Its main function is in charge of monitoring the fertility of the land. The responsibility of the organization to develop a definition of technology-specific sites that do not allow the reduction of fertility of the land, so farmers do not worry about it. At the suggestion of specific technologies and recommendations, the farmer gets the credit and is supported by the insurance company. If there is a recommendation given by the State Land Service, unforeseen expenses farm compensated by the insurance company.

[1, p.38] As can be seen from the above, the United States developed specific mechanisms to improve fertility.

Japan. In Japan in 1928 were initiated by the state the important work of raising the relationship to the land on the higher level. In 1949 accepted initiated, the law "On the improvement of the land" (TotiKayreho), and in 1952 "On the improvement of cultivated land" (KodoBayeeho). 
These two laws, based on the programs carefully worked out the state, overcame the problems related to land improvement, combining small areas, increasing soil fertility. Since 1965, as part of a tenyear government program on the improvement lands carried out the work associated with the amelioration of the land. Isolated and used for the first state program (1965-1974 y.) 2.6 trillion yen, and on the second - 32.4 trillion yen (1983-1993.). If the first program year invested an average of 0.26 trillion Ian, by the third program year on average spent 3.23 trillion yen. This is 13 times greater than the funds expended by the first program. And almost 90 percents of facilities of the last program are distinguished from the side of the state. [5]

China. China's population is about 1.3 billion people. Used land - 138 million hectares, which accounts for per capita 0.11 ha.

From 100 million ha of croplands 50 million ha is irrigated.

Talking about the quality of the land in China, it should be noted that 41 percent of the entire farmland belongs to the first zone, which has a high fertility. The second zone (average fertility) are 35 percent of the total arable land. The third zone - the infertile land, representing 20 percent of all arable land in China. 4 percent of the total arable land in China is considered to be unsuitable for agriculture.

In general, we can assume the quality of land in the middle China. 60 percent of all arable land is land that give low yields as a result of the negative effects of various objective factors. In particular, 8.5 percent of them are subjected to erosion, 11.4 percent are located on uneven areas, leading to erosion of land, 6.6 percent salt are coated in a layer of sand 10 percent is much greater than in fertile lands 35 percent are not fertile layer with sufficient depth, 0.4 percent - the rocky land, 9.3 percent is not enough provided with water, 1.1 percent do not have the required temperature. [2, p.67]

Thus, the limitations of land devoted to agriculture, very large population and high density, increased urbanization, high economic development of the country and by the withdrawal of land from agricultural use, as well as exacerbation of Ecology turned the problem of soil fertility and the effectiveness of its use in the most current issue of time. This, in turn, requires the development of specific measures to improve soil fertility, prevent the reduction of land, especially cultivated land.

Speaking about the measures undertaken in China to date to improve the fertility of the land, it is necessary to emphasize that the quality of the land in China is under strict government control. Control over land, conducting monitoring is ordered by the Law "On Land Management", adopted in 1986. State Bureau of Land Management, reporting directly to the State Council, deals with problems of preserving the integrity of the territory of the farm, especially arable land, incentives to improve soil fertility, as well as bringing to legal responsibility for the deterioration of the quality of the land.

Regulation "On the protection of basic arable land", adopted in 1994, promotes improvement of fertility of cultivated land and their protection. On the basis of the aforementioned documents to improve the fertility of the land used in agriculture, the following measures:

1. For the quality of arable land designated responsible managers have become, while evaluating their activities the main criteria for those activities to improve the fertility of arable land.

2. At the level of administrative units made up a master plan for land use. These plans are marked solid criteria that do not allow the reduction of arable land and reduce their fertility.

3. Intensified case plowing of virgin and abandoned lands.

4. Taking of inventory of all landed resources is conducted. State land management for several years due to huge amounts of money has made an inventory of land resources. In this process of land were assessed in both quantitative and qualitative terms. The collected data were used as valuable raw materials in the preparation of master plans land use.

Subsequently, legal documents improving fertility of cultivated land used for agriculture, much improved. Including in 1998 adopted a new edition of the Law "On Land Management." In 2004 were made to the amendments and additions. In this edition of the Law was increased the degree of responsibility for reducing soil fertility.

The results summarize the measures undertaken to improve the fertility of the land used in agriculture show that China dominates the market sharing arrangements and administrative methods to improve soil fertility. Its own it began to give results: in recent years, China has achieved notable success in the global market and the production of agricultural products. 
Turkey. Turkey is one of the leading in the world by territory. Of these, 44.3 percent is forest, 55.7 percent of the agricultural land, 81.6 percent of fertile irrigated land, 18.4 percent - irrigated irrigation method. Irrigated land in Turkey by volume ranks third in the European continent. Turkey became a member of the European Union intends to extend the area of fertile land in 41 million ha, which is 22 percent of the land of the European Union. [6]

It should be emphasized that in recent years Turkey has achieved notable successes in agricultural production: dates, dried apricots and raisins in the world ranked first, vegetables and grapes - fourth place, tobacco - sixth, cotton - seventh, wheat - eighth place. These successes are largely dependent on the measures implemented to improve the fertility of agricultural land. [4, p.195]

Turkey is of particular importance processes of the organization of large irrigation systems in order to increase the fertility of the land used in agriculture. In this regard, the project has gained great importance in South-Eastern Anatolia. As a result of the irrigation system significantly increased the volume of production of agricultural products.

By the state to improve the fertility of irrigated land allocated cash loans, in particular, to provide financial support for land users in Turkey, including allocated 2.65 billion turkish lira.

Russian Federation. Usage of agriculture land in the Russian Federation 220.7 million ha, or $12.9 \%$ of the country's land resources. It's 122.1 million ha of arable land, 1.8 million hectares of many annual plants, 24 million hectares of field, 68.0 million ha of pasture.

Land state monitoring and data analysis of the results of that decision, the Russian Federation, all units of land quality indicators intensive tempo is deteriorating. A total of 17.8 percent of the land is suitable and water erosion, and 8.4 percent of wind erosion, and 2.4 percent were subjected to wind and water erosion and joint. Excessive increased humidity, and waterlogged land makes up 12.3 percent of the total agricultural land. Salt affected land is equal to the share of $20.1 \%$.

It's clear that increasing the fertility of the land is today's one of the most punctual challenges of the Russian Federation. In this regard, the Russian government carries out a number of works on increasing the fertility of the land, and the implementation. Among events, the decision of the Government of the Russian Federation, in February 20, 2006, "The Russian national wealth as pertaining to the years 2006-2010 and 2013-based agricultural land to restore the fertility of the soil and agricultural landscapes and targeted federal program" play an important role.

The main aim of the program is using modern science and technology, agrochemical, drainage, technical and technological, through the implementation of the Water Resources and Agriculture on the basis of available land to improve soil fertility and land suitable for agriculture and agricultural landscape management use, to increase the production of high-quality agricultural products is to create the necessary conditions.

The program will lead to the expected effect of the following indicators:

- to avoid 5.55 million hectares of agricultural land out of agricultural turnover ;

- to attract 3.2 million hectares of not suitable land in agriculture turnover;

- 397 thousand hectares of land reclamation activities carried out in the commissioning;

- to attract 37 thousand hectares damaged land by Chernobyl nuclear disaster in agricultural turnover;

- 15.8 million tons of mineral fertilizers to the soil;

- protect 158.7 thousand hectares from land and water erosion, water pressure and the influence of under the ground water;

- to protect 585 thousand hectares of agricultural land from wind erosion and desertification;

- 2037.5 thousand hectares of gypsum and 475 thousand ha of phosphorus way to reduce the level of acidity of the soil;

- to keep workplaces in rural areas and to create about 108 thousands workplaces.

Planned program implemented in three stages.

The first phase, which includes the years 2006-2008 there, there planned tasks are almost fully completed. First of all, studies of the soil agrochemical and environmental and toxicological point of view, cartograms and agrochemical database was created, land users plans have been submitted and the introduction of agriculture-based system has been developed. 
At this stage, drainage systems intended for reconstruction and restoration of agricultural land irrigation, construction of hydraulic structures against erosion, as well was carried out the work on the implementation of the agrochemical.

The second phase (2009-2010), prepared report on the results of the implementation of a number of planned. According to estimates, 1,7 million hectares of agricultural land area designated for carrying out monitoring agricultural information systems based on soil fertility of agricultural land meant for complex large-scale Mapping was carried out. And, Russian Federation of units of 17 million hectares of land pertaining to the field of agricultural land agrochemical and environmental - toxicologic survey data were analyzed and drawn appropriate conclusions.

The third phase covers the years 2011-2012, this stage includes the first two of the planned events are considered to be delivered to the logical end.

Related Articles: Promoting labor civil servants

As the experience of above applications on improving the fertility of agricultural land, financing measures for improving the fertility of arable land in the first place by the state. However, the development of a mechanism to ensure using of land in the interest of improving its fertility plays an important role in maintaining and improving its quality.

In our opinion, based on international experience of stimulation to increasing of fertility of agricultural land for the same purpose, in Uzbekistan, you can apply the following measures:

performance guaranteed prices for products produced by those farmers who invest further improve the fertility of agricultural land, in particular, carry out activities related to the protection of water and land resources and increasing productivity of the land;

the provision of consultancy services to farmers on the basis of the development of technologies and recommendations necessary for site-specific, view these farms loans based on these technologies, and recommendations and conduct of insurance;

the use of reasonable proportions, as administrative and market mechanisms to stimulate the increase of fertility of agricultural land;

increase the role of tax incentives and other financial mechanisms and tools aimed to increase the fertility of agricultural land.

\section{CONCLUSION}

The results of the effective implementation of good practices, in particular, the implementation of the above measures will be shown in the stable development of farms the use of the agriculture, agricultural land and the degree of increase of their income, eventually - in improving the efficiency of agricultural production.

\section{REFERENCES}

1. Андреева Н. Сельское хозяйство США: факторы, определяющие высокую эффективность отрасли //Человек и труд. 2008. №8 -С 35.

2. Линь Фей Х. Рынок земли Китая в новых экономических условиях //Пробл. теории и практики упр. - 2009. - № 6. - С. 67.

3. Экономика США. /Подред. В. Б. Супяна. - СПб.: Питер, 2003. - С. 321.

4. İSTATİSTIKK GÖSTER GELER Statistical Indicators 1990-2016/ TÜRKIYYE İSTATİSTİK KURUMU Turkish Statistical Institute. Istanbul. 2016. — P.195

5. www.embjapan.ru

6. www.reach4turkey.com 